\section{Embedding Information Literacy in an MFA Novel Workshop}

\section{John Glover}

John Glover is Assistant Professor, Humanities
Research Librarian, VCU Libraries, Virginia
Commonwealth University, Richmond, Virginia.

Correspondence concerning this column should be addressed to Barry Trott, RUSQ Editor, 7770 Croaker Rd., Williamsburg, VA, 23188; email: btrott@wrl.org.

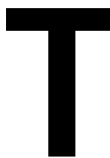

he rise of graduate creative writing programs in the United States during the twentieth century has been well documented. ${ }^{1}$ Less well documented is their connection with academic libraries, particularly in terms of their students' acquisition of research skills. When I was asked by a faculty member to provide in-depth support for the MFA novel writing workshop at Virginia Commonwealth University (VCU), there were a few articles treating this topic, a few references in creative writing pedagogy books, and a couple suggestive course titles listed in MFA program curricula. ${ }^{2}$ In 2012-13, I served as the embedded librarian in this year-long workshop. In that role, I worked with the faculty member to develop assignments that helped students to incorporate research into their fiction-writing practice, met with students for two lengthy research workshops, and subsequently met with students individually as their research deepened.

At VCU I engage in various research, instruction, and outreach activities, focusing on the humanities. Outside of work, my avocation is writing fiction, which I have done for many years, occasionally enrolling in workshops and publishing with some regularity. I took early note of VCU's MFA program, but had only modest professional interaction with it, aside from occasional consultations or email questions until Spring 2011, when I enrolled in a short story workshop led by Tom De Haven, an experienced writer, critic, and longtime faculty member in VCU's Department of English. Toward the semester's end, I compiled a list of research resources for the students in the workshop, along with links to electronic resources at VCU libraries. ${ }^{3}$

\section{WRITERS' DISTINCTIVE BLEND OF RESEARCH NEEDS}

When Tom De Haven and I met in Summer 2012 to start planning in earnest for the research component of the MFA novel writing workshop, I had sketched out some ideas based on my own practices as a writer, incorporating information literacy principles gained from library work. He wanted to ensure that students were prepared to find materials necessary to write their novels, and past experience had taught him that students often lacked the blend of skills necessary to do that. What did a street cleaner's cart look like in 1903 Chicago? Which forms of contraception might have been available in fourth-century Gaul? How much did a sandwich cost in Juneau in 1973? Who is still alive who knew Jimmy Hoffa? What does it feel like to suffer from the plague? This 
is a selection of the kinds of questions an author might have to answer in the course of writing a novel. To answer these questions requires a varied skill set.

While MFA students often arrive with basic information literacy skills, and sometimes more advanced skills learned in upper-level English language and literature courses, they do not typically have the combination of historical, investigative, image, and general research skills required to write novels, and which many novelists develop piecemeal over time. ${ }^{4}$ Our intent was to recreate that piecemeal process in an organized fashion for the students, at a point of need where they would be receptive to research training.

\section{STRUCTURE AND COURSE MATERIALS}

One of our first steps in preparing for this workshop was to determine the structure of the research component. Deciding early on the structure of the workshop's research component was critical. Given that the goal of the workshop is for students to complete a novel draft, anything hindering this goal would be unacceptable. Writers complete drafts of their novels in various fashions, but a common analogy is that of long-distance running, requiring steady progress over a long period of time. ${ }^{5}$ An additional complication is that novels frequently undergo substantial changes during the writing process, with the result that an author may be forced to rewrite or write entirely afresh substantial portions while midway through a draft, radically compressing their overall writing time.

We felt that the instruction had to be more than cursory exposure to research skills over the course of a brief session, so ultimately we chose to divide the instruction into two four-hour blocks, each taught on Saturdays during Fall Semester, a few weeks apart. The workshop's weekly meetings devoted to critiquing drafts ran just over two and a half hours each, so the research instruction amounted to a significant increase in their classroom time. In addition, I attended the first meeting of the workshop when introductions were made and participants discussed their novel plans and topics, so that I could tailor my demonstrations of resources to their needs. Ordinarily the workshop met in a seminar room, but on weekends we met in a computer lab in the classroom building that houses VCU's Department of English, where I could combine electronic resource demonstrations, handson print reference material discussions, and extensive inclass searching.

Choosing materials to support this instruction proved a challenge. While manuals exist for various related specialties, from investigative journalism to interviewing, no single book covers all of the research methodologies that a creative writer might need. ${ }^{6}$ Likewise, the topic is not covered in meaningful depth in creative writing manuals. Ultimately I brought to class and recommended students consider purchasing Don MacLeod's How to Find Out Anything: From Extreme Google Searches to Scouring Government Documents, a
Guide to Uncovering Anything About Everyone and Everything, which had just been published earlier in 2012. ${ }^{7}$ Books on research methodology published since then have largely focused on specific data types, disciplines, or tasks, and no newer book exists that is comparably broad in approach and readily digestible in style. The closest similar title is the fourth edition of The Oxford Guide to Library Research, published in 2015, which is richer but denser, and which I would recommend to individual writers as appropriate, but which I would be more likely to assign an MA class than an MFA workshop. ${ }^{8}$

\section{MANY ROADS}

As part of the initial planning process, De Haven and I discussed central concepts for the students to learn. I divided the instruction up into units covering fundamental areas including library research, primary sources, finding images, advanced web searching, researcher practices, government documents, investigating people, and publishing resources. Mapping the course content and structure to the ACRL Information Literacy Competency Standards for Higher Education was helpful in providing focus for all these disparate kinds of research, which can seem unrelated to the inexperienced researcher. ${ }^{9}$ This mapping helped us to embed the kind of tools they needed, but in a way that helped the students acquire information literacy skills relevant to their work as writers.

Finding a through-line for the units was occasionally challenging. This was not made easier by how different the resources might be from one hour (Artstor) to the next (RSS readers) to the next (American Memory). Some units ended with a teaser like "Have you ever wanted to be able track updates to blogs automatically? Next hour we'll talk about how to do that, and how to automate your research." In other cases I started a unit with the same subject matter from the previous hour, but showing how to research it using different resources. The students responded to these shifts with good humor, and we took breaks between different topics.

Examples I used during instruction were either directly applicable to workshop members' novel topics, or were similar enough to be obviously useful. Explicitly acknowledging the diversity of these tools while demonstrating their utility for the task at hand helped students to remain engaged. The frequency with which members of the class expressed interest in resources that were new to them, like The Firefly Visual Dictionary, or which they had not considered for research, like Twitter, helped reinforce the value of the class, as did De Haven's visible enthusiasm. ${ }^{10}$

\section{ASSESSING THE UNASSESSABLE}

Whether the effort of embedding in the workshop was "worth it" proved difficult to assess quantitatively. Unlike the 
other courses I support, where rubrics for assignments' successful completion are standard, assessing a student writer's first novel on its research use is challenging, even more so in a first draft. Whether students learned how to research is impossible to gauge from the work alone, as there is no universal standard for how much research should be incorporated into a novel, given variations in methods of writing and the style of the finished work.

When it comes to authorial knowledge, some hold that writers should know the entire iceberg, but only put the very peak on the page, whereas others hew to a "less is more" school of thought. I feel that it is difficult to use manuscript drafts to assess the extent to which workshop students have learned to carry out research. Such literary techniques as unreliable narrators, characters in whose mouths authors place false information, and information implanted obliquely in dialogue all help to confound straightforward attempts at assessment. Short of oral or written articulations by the students of their research practice, which both De Haven and I felt would have detracted from the goal of completing a novel draft, I concluded that detailed assessment was not feasible for this particular situation.

Assessment aside, workshop members were exposed to and practiced the kinds of skills used by novelists in their research. Over the course of the two weekends, each learned some things about research that were to their benefit, whether use of Google search operators or how to access digitized newspapers. This was reflected in their comments and level of activity during my interactions with them while circulating around the lab, during the hands-on portions of the workshops. Several students contacted me throughout the year with either in-depth reference questions or to schedule individual consultations. In all of these cases, the students' inquiries were complex, reflecting understanding and use of resources to which they had been exposed during the sessions.

\section{CONCLUSION}

Since the workshop ended, I have continued to provide support for VCU's creative writing program, offering increased numbers of research consultations and sharing information about developments at the library, from useful resources to events and other programming, as well as identifying useful overlaps with related fields. ${ }^{11}$ In Spring 2015 I co-led with De Haven an undergraduate fiction workshop that built on the work described in this article, developing further pedagogy to support writing researched fiction. In that course we taught side by side for the entirety of the semester. Course units were based around different kinds of research, coupled with writing assignments of various lengths to practice the research methods taught. A couple days each unit were particularly information literacy-heavy, featuring both instruction and class discussion of potential story ideas, allowing for group discussion of their research needs, which we ultimately followed up while in workshop with critiques of research along with the stories, and how well the one integrated the other.

Scholarship has developed in this area since 2013, with articles appearing on such topics as running National Novel Writing Month workshops and library services for creative writers. ${ }^{12}$ The literature of creative writing pedagogy did not address writers' information literacy needs prior to the research seminars I ran, and that has not changed..$^{13}$ Future studies would profit from more systematic analysis of student writers' information literacy needs and abilities, as well as articulating methodologies for assessment. As it stands now, information literacy instruction is clearly useful for this population, but it may shift very widely in nature, depending on what individual instructors see as important for their students. If there is any consistency in library services for creative writers, it is that the lack of creative writers' systematic articulation of their own information literacy needs means that library offerings will depend on the ability of librarians and creative writing programs to recognize useful opportunities for interaction.

\section{Acknowledgments}

I am grateful to Julie Arendt, Tom De Haven, Ken Irwin, and Sara Williams for their feedback as I worked on this article. I am grateful to VCU Libraries, and to Dennis Clark, who leads my division, for supporting this work.

\section{References and Notes}

1. Ben Siegel, The American Writer and the University. (Newark, NJ: University of Delaware Press, 1989); Mark McGurl, The Program Era: Postwar Fiction and the Rise of Creative Writing (Cambridge, MA: Harvard University Press, 2009); Chad Harbach, MFA vs NYC: The Two Cultures of American Fiction (New York: Faber and Faber / n+l Foundation, 2014).

2. Graeme Harper, Creative Writing Studies: Practice, Research and Pedagogy (Buffalo, NY: Multilingual Matters, 2008); Lauren Gibaldi, "Teaching Creative Writing at the Library," Florida Libraries 53, no. 2 (2010): 16-19; David Pavelich, "Lighting Fires in Creative Minds: Teaching Creative Writing in Special Collections," College \& Research Libraries News 71, no. 6 (2010): 295-313.

3. John Glover, "Creative Writing," VCU Libraries, last modified April 20, 2016, http://guides.library.vcu.edu/creative-writing. These included databases and items from VCU Libraries' circulating collection, as well as a research guide I had created previously.

4. A good example of this hybridity can be seen in Ronald Kovach, "A Devil of a Good Writer," Writer 116, no. 9 (2003): 20.

5. Sometimes this is a recurring metaphor, as in John Gardner, On Becoming a Novelist (New York: Harper \& Row, 1983). In one notable instance, the metaphor is the primary mover, as in Haruki Murakami and Philip Gabriel, What I Talk about When I Talk about Running: A Memoir (New York: Knopf, 2008).

6. One of the most recently published contains many sound principles, but too many pages of instructions for use of now-obsolete electronic resources: Mona McCormick, The Fiction Writer's Research Handbook (New York: New American Library, 1988). See also Jean Saunders, How to Research Your Novel (London: Allison \& Busby, 1993). 


\section{INFORMATION LITERACY AND INSTRUCTION}

7. Don MacLeod, How to Find out Anything: From Extreme Google Searches to Scouring Government Documents, a Guide to Uncovering Anything about Everyone and Everything (New York: Prentice Hall, 2012).

8. Thomas Mann, The Oxford Guide to Library Research, 4th ed. (London: Oxford University Press, 2015).

9. "Information Literacy Competency Standards for Higher Education," Association of College and Research Libraries, accessed June 20, 2012, www.ala.org/acrl/standards/informationliteracy competency.

10. Jean Claude Corbeil, The Firefly Five Language Visual Dictionary. (Buffalo, NY: Firefly, 2009).

11. Kristina Keogh and John Glover, "The Artist in the Library: Research Services for Creators" (poster presentation, Annual Conference of the College Art Association, Chicago, February 11-14, 2015).
12. Alex P. Watson, "NaNoWriMo in the AcadLib: A Case Study of National Novel Writing Month Activities in an Academic Library," Public Services Quarterly 8, no. 2 (2012): 136-45; Hugh Burkhart, "Creative Writing and the Web: Resources for the Literary Arts," College \& Research Libraries News 73, no. 3 (2012): 156-59; Julia Glassman, "Research Support for Creative Writers: Bolstering Undergraduate Fiction and Poetry Through Library Instruction," College \& Research Libraries News 75, no. 11 (2014): 602-9.

13. A notable exception to the general trend can be found in works on creative nonfiction, which may contain research instruction indexed as "Investigative Research," "Interviews," etc. Carolyn E. G. Forché and Philip Gerard, eds., Writing Creative Nonfiction (Cincinnati, OH: Story Press, 2001); Jack Hart, Storycraft: The Complete Guide to Writing Narrative Nonfiction (Chicago: University of Chicago Press, 2011). 